\title{
Privatization Experience and the Jordanian Economy
}

\author{
Abdullah Ali Al-Masaeed $^{1} \quad$ Prof. Evgeny Tsaregorodtsev ${ }^{2}$ \\ ${ }^{I}$ Ph.D student, Department of Economics and Finance, Mari State University, Russia, Part-time Lecturer, \\ Faculty of Finance, Business and Management, Department of Finance and Business, Economics, Al-Al Bait \\ University, Jordan, ${ }^{2}$ Department of Economics and Finance, Mari State University, Russia
}

DOI: $10.7176 / \mathrm{JESD} / 10-1-08$

\section{Introduction}

The wave of privatization began to sweep the world during the second half of the ninth decade of the twentieth century; England was one of the first countries that preceded it, followed by other developed countries such as France, Italy, Spain, Canada and others. Privatization has moved to developing countries such as Argentina, Brazil, Chile, Bangladesh, Pakistan, Turkey, Nigeria, Egypt, Jordan and others. The former socialist countries also began to adopt privatization programs such as the Soviet Union, Czech Republic, Slovakia, Poland, Hungary and others.

This trend emerged as a result of the conditions set by the International Monetary Fund and the World Bank in the run-up to the rescheduling of its debts "in accordance with the known rules of the Paris Club and the London Club", where the thought of these two institutions is based on the following analysis: ${ }^{1}$

"In order for these countries to avoid the difficulties of servicing their debts and their balance of payments problems, they need to restructure their economies so that they can improve the efficiency and allocate their resources, with a structural adjustment program; privatization comes from its most important components."

"World Bank experts believe that the policy of privatization needs to develop a program that starts a full survey of public sector projects and its problems, and classification of these projects according to their situation, and then identify projects to be privatized, with the establishment of the basis for evaluating the assets of the sold companies, and set a schedule that sets sales payments, and the establishment of a special body responsible for the privatization program. ${ }^{3}$

The Bank does not object to providing financial and technical support for the development and implementation of this program, the success of the program requires that the government of the state create an environment that will revive the market economy, such as: ${ }^{4}$

1. Edit prices, especially exchange rate, interest rate.
2. Liberalization of foreign trade.
3.
4.

As for Jordan, the process of privatization began in Jordan in 1992 with the implementation of the economic reform program in cooperation with the International Monetary Fund, which ended in 1998 and was extended three times until the end of the middle of 2004 but the pain of Jordan in 2009 of the impact of the global crisis and the resorting a large numbers in 2004 from Iraq and 2012 and 2013 because of the Syrian crisis made it difficult for them to continue without resorting to the World Bank and asked for loans from him and with each new loan required the lender for further reforms, including privatization, such operations will continue, including economic reform programs, within the framework of this program, a number of public companies and state-owned enterprises have been privatized or in which the State has a large share.

\section{First: The concept of public privatization}

There are many terms that have been launched into this process but one of the most common terms used in this term is the term privatization, which is the term used in this article, and there have been many definitions of privatization, some define it as a transfer of ownership of a project from the public sector to the private sector $^{5}$. In another definition, privatization refers to "the transfer of public ownership to the private sector, the management, rent, participation, sale and purchase of, or promotion or domination of, the State in various sectors

\footnotetext{
${ }^{1}$ See Reham Abdelmatti, Privatization and Economic Transformation in Egypt, Al Mahrousa Research and Publishing Center, Cairo, 1997, pp. 40,39.

${ }^{2}$ Mahmoud Sobh, Privatization to Meet Survival Requirements and Growth Challenges, Ain Shams University, Cairo, 1995, p. 15

${ }^{3}$ Mahmoud Sobh, op. Cit., P. 15, 16.

${ }^{4}$ Jamal Mahmoud al-Kurdi, Legal Regulation of Privatization, Dar al-Nahda al-Arabiya, Cairo, 1998, p.11

${ }^{5}$ Jamal Mahmoud al-Kurdi, Legal Regulation of Privatization, Dar al-Nahda al-Arabiya, Cairo, 1998, p.11
} 
of economic activity or the sphere of public services."1 In another definition, it is seen as "the process of transfer of ownership and operational management of state-owned enterprises to the private sector, either partially or wholly, and the private sector can be either foreign enterprises, businessmen or companies." ${ }^{2}$ in another definition, privatization refers to "the transfer of ownership of public enterprises to other parties managed by them in accordance with the principles of the private business sector" ${ }^{3}$. A third definition suggests that privatization is "to increase the efficiency of the management and operation of public enterprises by relying on market mechanisms and the elimination of bureaucratic arrangements." ${ }^{4}$ Among these definitions, it can be concluded that privatization is to increase the role of the private sector in the ownership, operation and management of productive units in society, with a view to improving the productive efficiency of these units to serve the objectives of economic and social development.

\section{Second: The objectives of privatization in Jordan}

One of the main characteristics of the economic situation in the Arab countries is the control of the public sector in these countries on a high percentage of economic activities and their penetration into all aspects of economic life, directly or indirectly. This dominance came from the state's possession of the elements of production, through nationalization and the establishment of public economic projects. And thus became most of the economic activities in the hands of the state (industry, banks, internal and external trade, construction, public utilities, transport, communications, etc.), the role of the private sector has declined, and it has almost disappeared during certain periods, and central planning has replaced the market system as an effective resource allocation force..$^{5}$ The public sector was supposed to make a positive contribution to the process of growth and development, but experience over the past years indicated that performance was below the required level. Using general indicators to measure efficiency, such as the amount of profits and losses, the deficit of the general budget, the rate of return on invested capital, the ability of the state to compete in foreign markets, etc., it is noted that the results in general are unsatisfactory, most public projects suffer consecutive losses, and the low yield and productivity, and a high proportion of production capacity is disabled and the inefficiency of most public sector institutions is the main reason for the growth of public debt. In most cases, its decisions did not take into account considerations of efficiency and productivity.

Thus, the objectives of privatization can be summarized as follows: ${ }^{6}$

1. Reallocation of roles between the public and private sectors, the gradual withdrawal of the state from certain economic activities and opened the way for private initiatives by encouraging private investment.

2. To reduce the burden on the state budget as a result of its support for the losing economic institutions, and to devote its resources to support the sectors of education, scientific research and health, and attention to infrastructure and economic institutions of strategic importance.

3. Developing the financial market and activating it and introducing mobility on the capital of companies in order to develop its productive capacity.

4. Create the right investment climate and encourage local investment to attract local, Arab and foreign capital.

5. Elimination of administrative sagging and financial corruption through privatization.

\section{Third: Methods of privatization in Jordan:}

1. Offering shares in a public offering (general or partial offering): "The public offering means that the Government shall put all or part of the shares of the company's capital for sale to the public, through the stock market. ${ }^{7 "}$ This is the best approach from an economic point of view; this method leads to an expansion of the ownership and competition base. In the event that governments sell a portion of their shares in the company, the result is that the company becomes a mixed government / private sector, and the purpose of such action may be to implement the policy of economic liberalization or the desire of the Government to maintain a its presence in the company or as a first step toward full privatization.

2. Offering of shares in a private placement: "Private placement means the sale of the shares of an

\footnotetext{
${ }^{1}$ Mustafa Mohamed Al-Abdullah, Structural Corrections and the Transition to a Market Economy in the Arab Countries, Center for Arab Unity Studies, Beirut, 1999, p. 47.

${ }^{2}$ Abdul Aziz bin Habtoor, Department of Privatization, Dar Safa, Amman, 1997, p. 6.

${ }^{3}$ Abdelkader Mohamed Abdelkader, Trends in Development, University House, Alexandria, 1999, p. 102

${ }^{4}$ Ibid., P.103

${ }^{5}$ See Dr. Abdul Qadir Muhammad Shehab, Different Methods of Privatization, Symposium on Economic Development in Libya, Tripoli, 14-16. 2002, p.3

${ }^{6}$ Mustafa Mohammed Al-Abdullah, previous reference, p. 36

${ }^{7}$ Dr. Mustafa Hussein Al Mutawakil, Privatization created new horizons for the private sector, National Information Center, Information Magazine, Aden, No. 2, March 2001, p. 1.
} 
enterprise or part thereof to a single investor or a select group of investors. Two common approaches to private placement can be distinguished: tendering, direct negotiation. ${ }^{1}$ This approach is preferred in the case of lowperforming companies or companies that need strong owners they have the industrial, financial and commercial expertise necessary for the success of companies, as well as strong financial support. ${ }^{2}$

3. Selling the assets of the company by public auction: It is noted in the previous two methods that the process of privatization is through the purchase by the private sector of the shares of the government company and invested in the performance of its activity, and this method takes the form of buying the assets of the company mainly, and this process is conducted by public auction.

4. Inject new private investment into the company: governments may not want to add more capital to the company they own, this often happens because of their desire to expand or modernize their operations, this is done by opening the door to contributing to the company's private sector capital.

5. Purchase of the management or employees of the company: The purchase of the management of the company means that a small group of managers control the capital of the company, and it is also possible to design a similar process through which employees or management with workers achieve the same control as before, the difference between the previous process and the completion of the purchase process through borrowing from banks, where buyers (management or workers) obtain bank credit to finance their access to the company, they offer the company's assets as collateral for this financing, and we note that privatization in developing countries is rare in this way, but common in the United States, where joint stock companies turn into private companies.

6. Leasing and management contracts: This method involves the hiring of experts from the private sector, to manage state-owned economic units, in exchange for certain fees, or to share the net profit with the State. $^{3}$ "This contract does not expose the tenant to any financial risk and the government company bears the full commercial risks, and the advantage of this contract is the government's retention of ownership of the company." 4 Management contracts are one of the ways of increasing privatization, because of several advantages, including: the most important of which are savings in service costs and to overcome the problem of non-flexibility of government employment with changes in the nature of work and its conditions. ${ }^{5}$

In Jordan, the Government of Jordan established a special unit in the Prime Minister in 1996, called the Executive Privatization Unit, ${ }^{6}$ its tasks are to summarized in privatization process within the general policy of the state, the privatization program in Jordan is considered one of the most successful programs in the Arab countries because of the speed at which it was implemented, "The total number of companies sold by the

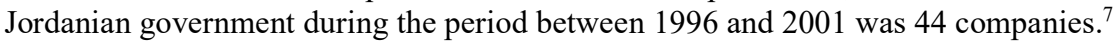

\section{Fourth: The justifications for privatization in Jordan}

1. The failure of economic restructuring programs that began in the 1970s.

2. Change and development in the philosophy of Jordanian economic thought by giving great importance to the subject of changing the form of ownership because of its role in improving the overall performance of companies.

3. The inability of the government to expand investment due to the deficit suffered by the public budget.

4. The inability of the public sector to keep pace with the local and foreign private sector in the production process in many sectors.

5. Reduce the burden of the budget by stopping subsidies and reducing the volume of internal and external indebtedness by reducing borrowing.

6. The Government's desire to break the cycle of monopoly practiced by some public institutions in some sectors.

7. Stopping governmental intervention in the production process in some sectors because their intervention impedes the expansion of investment and improving productivity.

\footnotetext{
${ }^{1}$ Dr. Ahmed Sakr Ashour, Transformation to the Private Sector, Arab Organization for Administrative Development, Cairo, 1996, p.166

${ }^{2}$ Mahmoud Sobh, op. Cit., P. 26.

${ }^{3}$ National Organization for Scientific Research, General Principles for Restructuring the Libyan Economy, Tripoli, 1992, p. 316.

${ }^{4}$ Dr. Sulaiman Abu Sabha et al., Privatization and Social Impacts on the Man of the Gulf, reading for all house for Publishing and Distribution, Dubai, 1996, p. 58

${ }^{5}$ Dr. Ahmed Maher, Director's Guide to Privatization, Center for Administrative Development, Alexandria University, Alexandria, 1998, p. 152.

${ }^{6}$ Moncef Abbas, Tunisia's Experience in Structural Reform and Privatization, Symposium on Economic Reforms and Privatization Policies in Arab Countries, Center for Arab Unity Studies, Beirut, 1999, p. 349

${ }^{7}$ The Unified Arab Economic Report, 2002, p.164
} 
8. The Kingdom's need to attract foreign currencies to support the balance of payments through direct and indirect foreign investments.

9. The performance of some public institutions deteriorated significantly.

This table shows the financial position for the calculation of privatization proceeds in Jordan up to 2009 and the value of one million dinars.

The financial position for the calculation of privatization $^{1}$ proceeds until September 2009, the value of one million dinars

\begin{tabular}{|c|c|c|}
\hline & Receipts & \\
\hline 1 & $\begin{array}{l}\text { Privatization proceeds of Jordan Telecom } \\
\text { Company }\end{array}$ & 940.1 \\
\hline 2 & $\begin{array}{l}\text { Privatization proceeds of Jordan Cement } \\
\text { Company }\end{array}$ & 79.8 \\
\hline 3 & Privatization proceeds from Royal Jordanian & 285.5 \\
\hline 4 & Privatization proceeds Arab Potash Company & 134 \\
\hline 6 & $\begin{array}{l}\text { Sale proceeds of } 37 \% \text { of the shares of Jordan } \\
\text { Phosphate Company }\end{array}$ & 81.4 \\
\hline 6 & $\begin{array}{l}\text { Proceeds from the sale of Royal Aviation } \\
\text { Academy }\end{array}$ & 4.1 \\
\hline 7 & Power Generation Company & 114.5 \\
\hline 8 & Irbid Electricity Company & 73.7 \\
\hline 9 & Returns of other companies & 10.3 \\
\hline \multicolumn{2}{|c|}{ Total } & 1723.4 \\
\hline & Expenses & \\
\hline 1 & purchase swap and restructure debt & 1562.7 \\
\hline 2 & refunds of privatization proceeds & 6.5 \\
\hline 3 & Refund of collateral for postal bonds & -156.7 \\
\hline 4 & $\begin{array}{l}\text { Repayment of loans and interest on property / } \\
\text { income tax and sales }\end{array}$ & 101.37 \\
\hline 5 & $\begin{array}{l}\text { Repayment of income and sales tax on the } \\
\text { property company }\end{array}$ & 1.3 \\
\hline 6 & $\begin{array}{l}\text { Projects of the economic and social } \\
\text { transformation program }\end{array}$ & 40 \\
\hline 7 & Financing development and other projects & 150.9 \\
\hline 8 & Civil and Military Housing Fund Projects & 26.5 \\
\hline 9 & $\begin{array}{l}\text { Provision for housing finance } \\
\text { program }\end{array}$ & 0 \\
\hline \multirow[t]{3}{*}{10} & $\begin{array}{l}\text { Repayment of loan installments( Housing } \\
\text { Fund) }\end{array}$ & -16.8 \\
\hline & Total & 1715.77 \\
\hline & Balance & 7.63 \\
\hline
\end{tabular}

Fifth: The Effect of Privatization on the Total Economy in Jordan ${ }^{2}$

The contribution of privatization to macroeconomic restructuring remained limited since the companies that have been privatized, although their importance was limited and their contribution to GDP was also limited compared to the countries in the region. On the foreign direct investment side, the Kingdom has coincided with the implementation of the program with relatively large inflows from abroad, came to finance the acquisitions of part of the government's properties in a number of companies that have been privatized, it was also accompanied by a general increase in foreign investment, accompanied by the elimination of restrictions that hampered the

\footnotetext{
${ }^{1}$ Bulletin of the Ministry of Finance for the month of December, 2009

${ }^{2}$ Report of Privatization Commission in Jordan, p.10
} 
entry of new competitors into these sectors. However, this flow of flows has not been sustained and stable, especially in light of the global financial crisis in 2008, which contributed to the decline of foreign investments to levels close to its levels before privatization.

On the public debt side, the government has started to use the majority of privatization proceeds to extinguish part of the Kingdom's external debt, thereby reducing its external indebtedness, this would have been an important achievement and would not have been accompanied by a significant increase in spending, a shift to domestic rather than external borrowing, and the importance of the difference between external and domestic borrowing, however, the ratio of debt to GDP has risen again due to the increase in government spending.

The most positive impact of the privatization program remains in the services sector, especially in the telecommunications, air transport, logistics and power generation sectors (IPPs), as these sectors no longer constitute a direct investment burden on the government and reflected the efficiency of the telecommunications sector and transport to other sectors, in sum, experience has shown that privatization cannot make sustainable changes in the structure of the national economy unless accompanied by medium- and long-term structural policies and programs aimed at strengthening the productive economy, diversifying energy sources and controlling government spending.

\section{Sixth: The impact of privatization on workers}

Privatization has had a positive impact on the level of workers' wages and the creation of direct and indirect employment opportunities in sectors that have been restructured. However, the impact of privatization differed on those employed in establishments privatized from one company to another and from one sector to another and from one worker to another. In general, the employees who have been established in their jobs have benefited greatly in terms of salaries, benefits and training, and their percentage is $80.6 \%$. Their annual wages have increased by more than the general average in the Kingdom in the majority of companies at rates ranging from $9-22 \%$ annually compared to the general rate of $5 \%$ per annum.

Either the laid-off workers and those who received pension payments, accounting for $9 \%$ of the total number of employees at the start of the privatization program, where they were motivated to retire for financial compensation at the rate of 31 thousand dinars each (with the large discrepancy between the company and others) and a total of financial incentives amounted to 189 million dinars paid by companies.

As for the less privileged group, a group of laid-off workers with a ratio of $10.4 \%$ who did not meet the conditions of retirement, but were dismissed for financial incentives and were unable to find alternative work. ${ }^{1}$

While privatizations have benefited the first category of workers and the second category often, but it damaged the last category of them, here we must distinguish between the importance of raising the productivity of the establishment on the one hand and the need to raise the productivity of the economy as a whole. From the perspective of the establishment, the priority is to retain the productive employment only, and disposal of surplus labor, which will enable them to raise their productivity and improve their competitiveness with other establishments. From the point of view of the economy as a whole, productivity only increases if the theater worker has got another job, and became more productive. States therefore focus on the rehabilitation of laid-off workers and on the need to reintegrate them into the labor market, whether as workers in other productive enterprises or on their own account.

The increase in the productivity of privatized enterprises does not necessarily reflect positively on the productivity of the economy as a whole when the surplus labor at the level of the establishment turns into unproductive forces at the level of the economy. This happened with the demobilized who did not return to the labor market in Jordan. Some retirees were deprived of rehabilitation and training, and others were denied the ability to combine their years of work between social security and civil service, which cause them to lose their rights to retirement Salary from both sides. Hence, financial compensation, despite its importance, does not compensate for the pension salary, or about the moral impact of those wishing to continue to work.

\section{Seventh: Results or Effects of Privatization in Jordan:}

1. Effects on corporate performance and on public treasury revenues.

2. Revenues continued after the privatization process in the form of profits, taxes and various fees.

3. Significant improvement in the financial performance of some privatized companies.

4. Good profitability levels for companies that have emerged from restructuring in the air transport sector.

5. Transformation of Jordan Telecom into one of the most important sources of tax income for the Treasury.

\footnotetext{
${ }^{1}$ Report of Privatization Commission in Jordan, p.12
} 
6. Preference of the financial investor rather than the strategic investor in the electricity production and distribution sector.

7. Privatization itself has not succeeded in achieving the desired economic objectives.

8. Has had a significant positive impact on the services sector, especially in the area of communications, air transport and electricity generation, as these sectors no longer constitute a burden in terms of direct investment from the Government.

The effects on the macro economy in Jordan were as follows:

1. Limited contribution to macroeconomic restructuring.

2. Large cash flows from abroad.

3. Increase in foreign investment.

4. Cancellation of contracts that hindered the emergence of new competitors.

\section{Impacts on staff included:}

1. Increase salaries for staff members who remain in office.

2. Financial retirement benefits for eligible employees to retire.

3. Financial incentives for terminated employees.

Eighth: Recommendations:

The final outcome is that the Jordanian experience is the same as the current international experience believes that privatization is a means, not an end in itself, and is not necessarily the panacea for every problem. Its success or failure depends on the organizational environment, the structure of the market, the transparency of the process, the content of the agreements and the ability to monitor them and follow them later. The process of privatization in Jordan was somewhat successful, but there are some mistakes that we have made to recommendations, Such as:

1. Raise public awareness about the objectives of privatization.

2. Enhancing transparency in procedures and disclosure of results.

3. Consider privatization as a means to achieve a specific development objective for the public good.

4. Structuring the sector to ensure fair competition and reduce the monopolistic period to stimulate growth and economic efficiency.

5. Separate the source of funding from the management and operation process.

6. Feasibility study on alternatives to public-private partnership before resorting to privatization.

7. The good conduct of the proceeds of privatization and not as Jordan has done, all revenues are directed to debt service.

8. To transfer the proceeds of privatization to investment projects through which it can eliminate unemployment and repay debts.

\section{References}

Abbas, M. (1999) Tunisia's Experience in Structural Reform and Privatization, Symposium on Economic Reforms and Privatization Policies in Arab Countries, Center for Arab Unity Studies, Beirut, p. 349

Abdelkader, M. (1999) Trends in Development, University House, Alexandria, p. 102

Abdelmatti, R. (1997) Privatization and Economic Transformation in Egypt, Al Mahrousa Research and Publishing Center, Cairo, pp. 40,39.

Abu Sabha et al. (1996) Privatization and Social Impacts on the Man of the Gulf, reading for all houses for Publishing and Distribution, Dubai, 1996, p. 58

Al-Abdullah, M. (1999) Structural Corrections and the Transition to a Market Economy in the Arab Countries, Center for Arab Unity Studies, Beirut, p. 47.

Al-Kurdi, J. (1998) Legal Regulation of Privatization, Dar al-Nahda al-Arabiya, Cairo, p.11

Al Mutawakil, M. (2001) Privatization created new horizons for the private sector, National Information Center, Information Magazine, Aden, No. 2, March, p. 1.

Ashour, A. (1996) Transformation to the Private Sector, Arab Organization for Administrative Development, Cairo, p.166

Bin Habtoor, A. (1997) Department of Privatization, Dar Safa, Amman, p. 6.

Maher, A. (1998) Director's Guide to Privatization, Center for Administrative Development, Alexandria University, Alexandria, p. 152. 
National Organization for Scientific Research (1992) General Principles for Restructuring the Libyan Economy, Tripoli, p. 316

Shehab, A. (2002) Different Methods of Privatization, Symposium on Economic Development in Libya, Tripoli, 14-16., p.3

Sobh, M. (1995) Privatization to Meet Survival Requirements and Growth Challenges, Ain Shams University, Cairo, p.15

The Unified Arab Economic Report (2002), p.164

Bulletin of the Ministry of Finance for the month of December, 2009

Report of Privatization Commission in Jordan, p.10

Report of Privatization Commission in Jordan, p.12 